\title{
Production of Scholarly Articles by Academic Librarians and Library School Faculty
}

\author{
Paula D. Watson
}

Eleven major journals in the field of librarianship were examined for the period 1979 through 1983 to determine the affiliation of authors of substantive articles. Findings indicate that requirements for academic librarians to publish affect publication productivity. Results concerning the productivity of library school faculties are fairly consistent with the findings of an earlier quantitative study. Suggestions for further analysis are included.

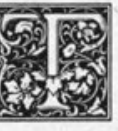

here have been studies done in several disciplines, which rank academic departments at various institutions in terms of their contributions to a selected group of major journals in their field. ${ }^{1}$ Such studies are generally conducted to provide some measure of the excellence of the academic programs in question on the presumption that faculties that are productive in publishing will provide a high-quality educational program for students. The presumption that excellence in teaching is tied to excellence in research is widespread in the American higher education community. ${ }^{2}$ Comparative studies of faculty publication productivity therefore claim to provide guidance for graduate students who want to identify the best schools in their field. Also, the studies purport to provide information to young academics who are seeking jobs in departments likely to have a high status in the field and to provide a stimulating intellectual atmosphere conducive to professional growth. Publication output studies also examine "the sociology of the literature $^{\prime \prime 3}$ in a particular discipline by deter- mining who publishes where and what they publish.

The primary purpose of the research reported in this article was to examine the affiliation of authors of articles published during the period 1979 through 1983 in eleven major library science periodicals. The reasons for undertaking the study are related to those described above for similar studies in other disciplines. First, since library school faculty are included in the study, the results may provide some measure of the excellence of library school programs and, thus (as is claimed for studies in other disciplines), may supply some guidance to both prospective students and faculty job seekers in library science. Almost half of the authors of articles in the eleven journals selected for analysis are practicing academic librarians. Since many of the articles written by academic librarians are descriptions and/or evaluations of innovations in the practice of librarianship, it might be argued that libraries with a high rate of publication productivity provide a stimulating work environment in which experimentation with new approaches and techniques is

Paula D. Watson is assistant director of general services for central reference services at the University of Illinois, Urbana, Illinois 61801. 
encouraged. Librarians seeking such work environments might refer to the results of this article in a job search, although innovations in librarianship are not limited to those libraries that encourage librarians to publish. A third potential use of the findings is as a measure of the degree to which librarians with faculty status are successful in meeting standards for research and subsequent publication productivity applied to faculty in other fields. Obviously, the selection of journals to be analyzed is, to some degree, subjective (see below for selection criteria). Also, the writing of articles in the general library journals chosen for this study constitutes only one of the publication opportunities available to both librarians and library school faculty. The study ignores the publication of books, chapters in books, reports, and articles in more specialized journals either in librarianship or in other subject fields. In a study of the publication output of librarians at ten academic libraries during the period 1969/70 through 1973/74, Watson found that, "If book reviews are discounted, it is evident that the librarians surveyed publish at least as frequently in journals outside the field of library science as they do in journals in the field. ${ }^{\prime \prime}$

\section{METHODOLOGY}

The journals chosen for analysis were College $\mathcal{E}$ Research Libraries, Information Technology and Libraries (formerly Journal of Library Automation), Journal of Academic Librarianship, Journal of Library History, Library and Information Science Research (formerly Library Research), Library Journal, Library Resources \& Technical Services, Library Quarterly, Library Trends, $R Q$, and Serials Librarian. Four are the official journals of American Library Association divisions and are therefore of obvious centrality to the literature. The others have all been published during the entire survey period and some are among the best-known and most well-established journals in the field. They provide an outlet for the ideas of a very broad range of librarians and library educators and deal with many of the predominant concerns in the field. All are refereed journals or contain articles by invita- tion, both stringent methods of article selection that carry with them an indication of recognition for the author and for the institution with which he or she is affiliated. Of course, as was indicated earlier, focusing on the journals of more general content to some extent ignores the contribution of the specialist to the overall publication productivity of library school faculties or academic library staffs.

Each article was coded for the institutional affiliation of the author and, for practicing librarians, by type of library (i.e., public, academic, etc.). For multiauthor papers, credit was assigned fractionally to each author. Therefore, for papers with two authors, each author was given .50 credits, and so on down to fiveauthor articles, for which each author was assigned .20 credits. Institutional credit was assigned on the same fractional scale. The information on affiliation was taken from the text of the article as it appeared in the journal or from the list of contributors. If the author had moved recently, credit was given to the institution at which the work had been done if that could readily be determined. (In fact such determinations were generally quite easy to make.) Book reviews, research notes, contributions, and regular columns were excluded from consideration. No judgments were made as to the quality of the articles and no exclusions were made on the basis of length, except in cases where the journal editor seemed to be making a distinction between full-fledged research articles and "notes" or "contributions." Editorships of journal issues and papers presented at conferences and reprinted in journals were counted as articles.

Libraries were coded by type as follows: public, special, academic, state, national (including the national libraries of foreign countries), school, and other libraryrelated organizations. The latter category included staff of networks and consortia and organizations such as the Council on Library Resources or the Association of Research Libraries. Other categorizations for authors were teaching faculty and graduate students in other fields (e.g., economics, marketing, business administration, English, etc.), members of the cor- 
porate sector (e.g., booksellers, information industry personnel, and library consultants), and a general category for "others," which included, for example, free-lance writers and government officials. Library school professors were coded by academic rank whenever this information was provided; students and emeritus professors were counted separately. Despite the difficulty of determining exactly what work individuals do based on their titles as recorded in the credits of journal articles, the positions held by working academic librarians were also recorded for use in a possible future analysis to involve examination of correlations between article subject content and the job held by the author.

Publication Productivity by

Journal and by Type of Author's

\section{Institutional Affiliation}

The study analyzed a total of 1,537 articles that appeared in the eleven selected journals during the period 1979 through 1983. Table 1 illustrates the distribution of the articles by journal and by the institutional affiliation of the authors. The most productive class of authors is that of academic librarians followed by library science faculty. Olsgaard and Olsgaard found similar results in their study of the contributions during the ten-year period 1967 through 1977 to five library science journals: College \& Research Libraries, Library Journal, Library Quarterly, and Library Trends. ${ }^{5}$ The Olsgaards point out that library science faculty publish more in proportion to their numbers than do academic librarians. This is not surprising since not all academic librarians (even those with faculty status) are required, nor do they have the incentive, to publish; whereas, presumably research and publication is a duty implicit in the job definition of most library science faculty. They are also encouraged by benefits gained (e.g., tenure, salary raises) to publish. A 1980 study by Rayman and Goudy found (based on a 72 percent response) that librarians at only 15 percent of Association of Research Libraries "are required to publish. ${ }^{\prime 6}$ This finding is consistent with

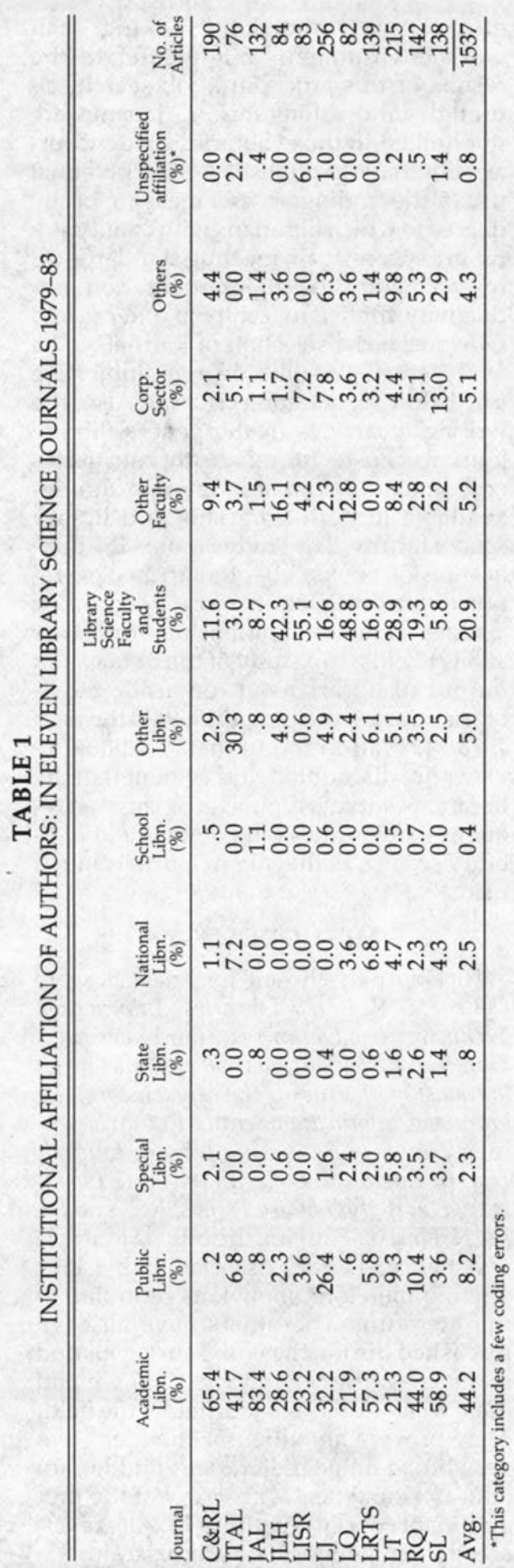


results of a later study of ARL members by English. Based on a 100 percent response, English found that librarians at only fifteen (16.9 percent) of ARL libraries are evaluated through the "use of traditional faculty criteria" and that at almost all these institutions a "blend of professional and faculty criteria" are employed in evaluation.?

Table 1 shows high concentrations of articles from particular types of institutions being published in particular journals. Not surprisingly, academic librarian authors are the primary contributors to $\mathrm{Col}$ lege $\mathcal{E}$ Research Libraries and to the Journal of Academic Librarianship. On the other hand, library school faculty predominate as authors of articles in the Journal of Library History, Library and Information Science Research, and Library Quarterly. Many articles in Information Technology and Libraries are written by personnel from "other libraryaffiliated organizations," the staff of library networks, consortia, and bibliographic utilities. Some of these authors are not librarians, but are programmers or other technical specialists. Direct comparison of the present results for the five journals examined in the Olsgaard study is difficult because those authors used a different method for assigning publication credits, giving all authors on multiauthored papers full instead of partial credit. However, a few divergences from the findings of the earlier study for specific journals may be significant. Olsgaard and Olsgaard found that academic librarians accounted for 18.9 percent of the contributions to Library Journal, while the present study found they accounted for a much higher proportion (32.2 percent) of the articles. Another potentially significant difference is that library science faculty and students increased their contributions to Library Quarterly from the 34.4 percent found by the Olsgaards to the 48.8 percent found in the present study (seemingly largely at the expense of faculty in other fields). ${ }^{8}$

\section{Publication Productivity of Libraries}

Two hundred and ninety-two academic libraries were represented in the sample, but few had many published authors. The vast majority of libraries were represented by only one article in the sample. Table 2 lists the twenty most productive institutions. For academic libraries, the table also shows the status, benefits, and privileges enjoyed by librarians at those institutions that may encourage research and publication. This information was derived mainly from English's excellent and painstaking study of librarian status at eighty-nine U.S. members of the Association of Research Libraries. ${ }^{9}$ As a check on the effect of size on the productivity of various libraries, per capita production is also included in column 2 of table 2 . At twelve (63 percent) of the twenty most productive libraries, librarians have faculty status, according to English, as well as the major benefits and privileges that encourage research and publication, namely, eligibility for indefinite tenure, access to funds in support of research, access to travel funds, and eligibility for both sabbaticals and research leaves. What is perhaps more surprising is the high percentage of institutions listed in appendix $B^{10}$ of the English article (i.e., those whose administrators claim that their library faculty are judged using the same criteria used to judge the teaching faculty) that appear among the twenty most productive publishers in this survey. English states that fifteen libraries in the ARL (or 16.9 percent) "claimed that the criteria used for evaluating librarian performance were the same as those used for the regular teaching faculty. ${ }^{\prime 11}$ However, careful analysis of the criteria provided by the responding libraries (listed in English's appendix B) indicates that only ten of the fifteen actually specify that research and publication are included in the performance evaluation criteria used in evaluating librarians, and one of these (Tennessee) implies that either "scholarship, research, creative accomplishment, or professional development" (emphasis is the author's) are acceptable. ${ }^{12}$ (English's information for Illinois is, incidentally, incorrect. Illinois has stressed research and publication in its standards for judging librarians since 1977.) Oregon, which undoubtedly once would have made an eleventh library in- 
TABLE 2

TWENTY MOST PRODUCTIVE LIBRARIES: STATUS, BENEFITS, AND PRIVILEGES OF LIBRARIANS*

\begin{tabular}{|c|c|c|c|c|c|c|c|c|c|c|c|}
\hline Library & $\begin{array}{c}\text { Number } \\
\text { of } \\
\text { Publi- } \\
\text { cations } \\
\text { (1) }\end{array}$ & $\begin{array}{c}\text { Per } \\
\text { Capita } \\
\text { Produc- } \\
\text { tivity† } \\
\text { (2) }\end{array}$ & $\begin{array}{c}\text { Faculty (F) } \\
\text { or Profes- } \\
\text { sional (P) } \\
\text { Status } \\
\text { (3) }\end{array}$ & $\begin{array}{c}\text { Faculty } \\
\text { Rank } \\
(4)\end{array}$ & $\begin{array}{c}\text { Indef- } \\
\text { inite } \\
\text { Tenure } \\
(5)\end{array}$ & $\begin{array}{l}\text { Contin- } \\
\text { uing } \\
\text { Appoint- } \\
\text { ments } \\
(6)\end{array}$ & $\begin{array}{c}\text { Research } \\
\text { Funds } \\
\text { (7) }\end{array}$ & $\begin{array}{c}\text { Travel } \\
\text { Funds } \\
(8)\end{array}$ & $\begin{array}{l}\text { Research } \\
\text { Leave } \\
\text { (9) }\end{array}$ & $\begin{array}{l}\text { Sab- } \\
\text { batical } \\
\text { Leave i } \\
\text { (10) }\end{array}$ & $\begin{array}{c}\text { Criteria } \\
\text { Same } \\
\text { as Teach- } \\
\text { ing Faculty } \\
\text { (11) }\end{array}$ \\
\hline $\begin{array}{l}\text { 1. University of Illinois at Urbana-Champaign } \\
\text { 2. Library of Congress }\end{array}$ & $\begin{array}{l}52.30 \\
22.70\end{array}$ & $\begin{array}{l}.43 \\
.008\end{array}$ & $\mathrm{~F}$ & $\mathrm{x}$ & $x$ & & $x$ & $x$ & $x \neq$ & $x$ & $x \ddagger$ \\
\hline 3. Ohio State & 17.16 & .16 & $\mathrm{~F}$ & $\mathrm{x}$ & $\mathrm{x}$ & & $x$ & $x$ & $\mathrm{x}$ & $x$ & $\mathrm{x}$ \\
\hline 4. Oregon & 13.00 & .28 & $\mathrm{~F}(1)$ & $x$ & & 1 & $\mathrm{x}$ & $x$ & $\mathrm{x}$ & $\mathrm{x}$ & $\mathrm{x}$ \\
\hline 5. Pennsylvania & 12.00 & .13 & $\mathrm{P}$ & $\mathrm{n}$ & & $\mathrm{x}$ & $x$ & $x$ & $x$ & & \\
\hline 6. California-Berkeley & 10.50 & .07 & $\mathrm{P}$ & e & & $x$ & $x$ & $x$ & $\mathrm{x}$ & & \\
\hline 7. New York University & 10.33 & .12 & $\mathrm{~F}$ & $\mathrm{e}$ & $x$ & & & $x$ & & $x$ & $x$ \\
\hline 8. Northwestern & 10.00 & .09 & $\mathrm{P}$ & $\mathrm{n}$ & & $\mathrm{x}$ & $\mathrm{x}$ & $x$ & $\mathrm{x}$ & & \\
\hline 9. Purdue & 10.00 & .13 & $\mathrm{~F}(2)$ & $x$ & $x$ & & $x$ & $x$ & $x$ & $x$ & $x$ \\
\hline 10. Southern Illinois & 10.00 & .16 & $\mathrm{~F}$ & $\mathrm{x}$ & $\mathrm{x}$ & & $\mathrm{x}$ & $\mathrm{x}$ & $\mathrm{x}$ & $x$ & $\mathrm{x}$ \\
\hline 11. Michigan & 9.33 & .07 & $\mathrm{P}$ & e & & $x$ & $x$ & $x$ & $x$ & & \\
\hline 12. University of Illinois at Chicago & 9.00 & .12 & $\mathrm{~F}$ & $x$ & $x$ & 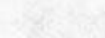 & $\mathrm{x}$ & $\mathrm{x}$ & $\mathrm{x}$ & $x$ & $\mathrm{x}$ \\
\hline 13. Pennsylvania State & 9.00 & .09 & $\mathrm{~F}$ & $\mathrm{e}$ & $x$ & & $x$ & $x$ & $\mathrm{x}$ & $\mathrm{x}$ & \\
\hline 14. SUNY-Albany & 8.66 & .17 & $\mathrm{~F}$ & $\mathrm{e}$ & $x$ & & $\mathrm{x}$ & $x$ & $\mathrm{x}$ & $x$ & \\
\hline 15. SUNY-Buffalo & 8.33 & .09 & $\mathrm{~F}$ & e & $x$ & & $\mathrm{x}$ & $x$ & $\mathrm{x}$ & $\mathrm{x}$ & \\
\hline 16. California-Los Angeles & 8.00 & .05 & $\mathrm{P}$ & $\mathrm{e}$ & & $\mathrm{x}$ & $\mathrm{x}$ & $x$ & $x$ & & \\
\hline 17. Minnesota & 7.70 & .06 & $F(2)$ & $\mathrm{x}$ & $x$ & & $\mathrm{x}$ & $x$ & $x$ & $x$ & $x$ \\
\hline 18. New Mexico & 7.66 & .17 & $F$ & $\mathrm{x}$ & $x$ & & $x$ & $x$ & $x$ & $x$ & $\mathrm{x}$ \\
\hline $\begin{array}{l}\text { 19. Iowa State } \\
20 \text { Viroinia Polvtechnic }\end{array}$ & $\begin{array}{l}7.50 \\
7.16\end{array}$ & .15 & $\begin{array}{l}\mathrm{F} \\
\mathrm{F} \delta\end{array}$ & $x$ & $x$ & & $\stackrel{x}{x}$ & $x$ & $x$ & x & \\
\hline 20. & 1.10 & .13 & F8 & $\mathrm{x}$ & & $\mathrm{x}$ & some & $\mathrm{x}$ & $\mathrm{x}$ & II & \\
\hline
\end{tabular}

Explanation of symbols: $\mathrm{x}=$ yes; $\mathrm{e}=$ equivalent rank; $\mathrm{n}=$ numerical ranks; $1=$ librarians are placed in two, distinct faculty categories; $2=$ mix of faculty and professional positions.
"The information in columns 3 through 11 for all universities except the University of Illinois at Chicago and Virginia Polytechnic and State University is derived from Thomas G. English, "Librarian "The information in columns 3 through 11 for all universities except the University of Illinois at Chicago and Virginia Polytechnic and State University is derived from Thomas G. English, "Librarian
Status in the Eighty-Nine U.S. Academic Institutions of the Association of Research Libraries: 1982," College \& Research Libraries 44: appendixes A and B (May 1983). Information on the remaining two universities was obtained by telephone conversation with administrative officers of the libraries.

tPer capita productivity for ARL libraries was computed by dividing the quantities in column one by the number of professional librarians listed in Carol A. Mandel and Alexandex Lichtenstein, comps. ARL Statistics: 1982-3 (Washington: Association of Research Libraries, 1984). The figures for Virginia Polytechnic and the University of Illinois at Chicago were computed by dividing the quantities in column 1 by the number of professional librarians listed for each institution in the American Library Directory, 36th ed. (New York: Bowker, 1983)

$\ddagger$ Librarians at the University of Illinois at Urbana-Champaign are eligible for research leave, even though English's article referred to above does not so indicate. Research is also among the criteria used to evaluate UIUC librarians even though it is not mentioned in English's appendix B.

§Until 1983 librarians had full faculty status and were eligible for indefinite tenure. In 1983 librarian status at VPI was redefined as "noncollegiate status." Librarians no longer stand for tenure review, but are eligible for continuing appointments.

ISabbaticals do not exist in the traditional sense for any faculty at VPI. 
cluding research and publication in its performance standards, did not provide a list of criteria to English. This library has undergone a change in librarian status and presumably research and publication criteria no longer apply. ${ }^{13}$

It is a striking fact that seven of the ten ARL members found by English to be employing research and publication criteria in judging library faculty are among the top twenty most productive academic libraries in terms of publishing. An eighth (not an ARL library) that employs true faculty performance criteria in judging librarians is the University of Illinois at Chicago. Including this library, 42 percent of the academic libraries among the top twenty most productive publishers provide not only the benefits of faculty status to librarians but also impose its requirements upon them. It might be noted in passing that English finds a large number of ARL librarians have the benefits that are conducive to doing research and yet do not seem to be required to do so: 46 percent have what is called faculty status, 42.6 percent are eligible for indefinite tenure, 64 percent are eligible for research leave, 50.6 percent are eligible for sabbatical leave, 93.2 percent have access to research funds, 100 percent are eligible for travel funds. ${ }^{14}$ Yet librarians from most of these libraries are not heavily represented as authors in the present sample.

It should be noted that eleven of the top twenty in publication productivity either do not have faculty status at all or, if they do, they do not have the incentive of evaluation according to true faculty criteria. Except in the case of Illinois (UrbanaChampaign), there is not a marked difference in productivity between those who must meet true faculty standards (including research and publication) and those who need not.

The Illinois situation is by any measure unique. Illinois is far and away the most productive of the academic libraries in the top twenty, even though analysis by per capita productivity provided in column 2 of table 2 does bring Oregon closer to it in relative standing. (Otherwise, the spread in productivity increases somewhat, through the introduction of the size factor, but not dramatically, except in the case of the Library of Congress.) The University of Illinois has a strong commitment to the involvement of librarians in scholarly pursuits, strives for a truly collegial milieu, enforces stringent evaluative criteria, and gives heavy weight to research and publication in its evaluation of librarians both for promotion and tenure and for annual salary increases. ${ }^{15,16}$

\section{Publication Productivity of Library School Faculty}

Although the primary focus of this paper was to be on the publication productivity of academic libraries, results for library school faculty were also tabulated. Eighty library schools were represented in the sample (including schools in foreign countries), but 61 percent of the articles contributed to the journals in the sample were written by library educators at fifteen schools. Table 3 lists in rank order these fifteen most productive schools and the number of articles each contributed to the sample. In his review of studies ranking professional library schools, Danton found that only one, by Hayes, ${ }^{18}$ relied on quantitative data. Although Hayes' methodology is completely different from that employed in the present study and his sample is also considerably different, eleven of the same schools appear among the top fifteen producers in both the Hayes and the present study. They are in

TABLE 3

\section{FIFTEEN MOST PRODUCTIVE LIBRARY SCHOOLS}

\begin{tabular}{lc}
\hline \hline Library School & Number of Publications \\
\hline 1. Chicago & 21.00 \\
2. Columbia & 18.50 \\
3. Indiana & 15.00 \\
4. North Carolina & 13.45 \\
5. California-Berkeley & 12.50 \\
6. Illinois-Urbana/Champaign & 11.70 \\
7. Wisconsin-Madison & 10.50 \\
8. Kentucky & 10.00 \\
9. California-Los Angeles & 10.00 \\
10. Minnesota & 9.50 \\
11. Maryland & 9.00 \\
12. Toronto & 8.50 \\
13. Drexel & 8.33 \\
14. Michigan & 8.00 \\
15. Rutgers & 8.00 \\
\hline
\end{tabular}


different rank-order except for the University of Chicago, which is number one on both lists. Table 4 presents library school article productivity by academic rank. The results are somewhat skewed since one journal, Library and Information Science Research, in which library educators publish frequently, chooses not to include rank in its descriptions of authors in almost every case. Individuals in the "unspecified rank" category also frequently include deans, since their academic ranks are often not supplied. An article by Bidlack, which gives the percentage distribution of lecturers, instructors, assistant professors, associate professors, and professors and lists deans and directors separately, is used to establish norms for the populations in the various ranks for purposes of comparison with their productivity. ${ }^{19}$ Associate professors are publishing in proportion to their numbers, but assistant professors and full professors, at least based on this sample, appear to be doing somewhat less than might be expected.

\section{Discussion}

The study was undertaken to identify academic libraries and, to a lesser extent, library schools at which significant amounts of publication are taking place. Publication by librarians at academic libraries is seen as an indication of an innovative, progressive library environment. The identification of libraries in which it takes place may therefore serve as an aid to job seekers in the academic library market. Similar but more modest claims for the usefulness of the data on library schools to prospective students and job seekers may also be made. However, for both types of institutions the publication outlets studied represent only a portion of the publication opportunities available to librarians and library school faculty, and this limitation may have even more significance for library school faculty than for librarians.

As to the findings on the publication productivity of academic libraries, it is clear that the University of Illinois at Urbana-Champaign occupies a unique position in terms of output relative even to institutions that claim to be meeting the

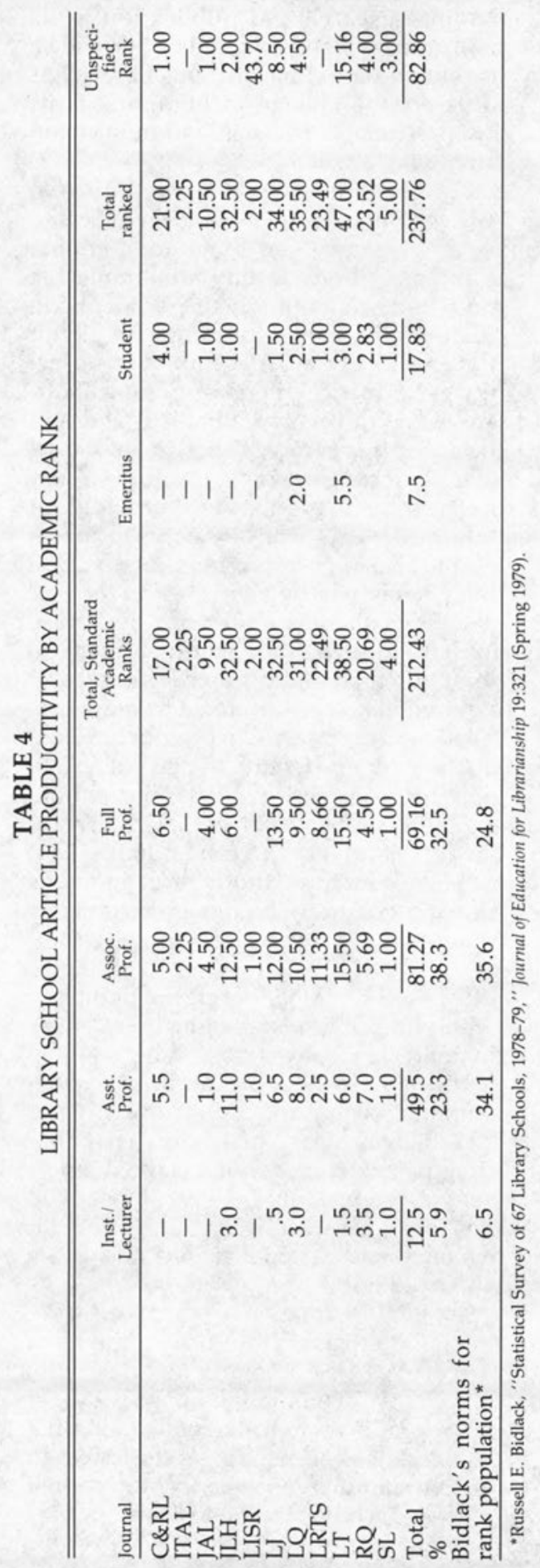


same level of performance criteria. Among the most productive libraries, librarians who do not have faculty status seem to publish at about the same rate as librarians at institutions where librarians do have faculty status. Still, based on English's data on criteria, it appears that the requirement to publish serves, not surprisingly, as a strong incentive to do so.

Further work on the data collected for this study will include an analysis of au- thor characteristics by gender, age, professional experience, position held, and the subject content of articles published. The degree to which librarians with less than six years of professional experience are successful in breaking into print is clearly central to the true success and equity of a full faculty status system for librarians in which both the benefits and the requirements of such a system are completely embraced.

\section{REFERENCES AND NOTES}

1. Examples of such studies include: Karin McCallum, "Research/Publication Productivity of U.S. Speech Communication Departments," The Southern Journal of Speech Communication 49:135-42 (Winter 1984); Lawrence C. Soley and Leonard N. Reid, "Advertising Article Productivity of the U.S. Academic Community," Journalism Quarterly 60:464-69, 542 (Autumn 1983); L. Barker and others, "An Investigation of Articles Produced in the Communication Discipline by Institution: 1970 through 1978," ACA Bulletin 30:18-22 (Oct. 1979); W. M. Cox and V. Catt, "Productivity Rankings of Graduate Programs in Psychology Based on Publication in Journals of the American Psychological Association," American Psychologist 32:793-813 (1977); C. West, "Productivity Ratings of Institutions Based on Publication in Journals of the American Educational Research Association: 1970-1976," Educational Researcher 7:11-14 (1978); Richard R. Cole and Thomas A. Bowers, "Research Article Productivity of U.S. Journalism Faculties," Journalism Quarterly 50:246-54 (1973); L. S. Lewis, "On Subjective and Objective Rankings of Sociology Departments," American Sociologist 3:129-31 (May 1968).

2. Representative of this viewpoint is the following quote from an internal University of Illinois document concerning criteria for promotion and tenure at that institution: "A teacher with little or no record of scholarship or creative endeavor will rapidly grow stale. . . . The best teacher should be one who is aware of the leading edge of a field, and the most effective way to be aware of the leading edge is to be a part of it." University of Illinois at Urbana-Champaign. Office of the ViceChancellor for Academic Affairs. 1978-79 Academic Affairs Communication, no. 9 (mimeographed, 1978), p.5.

3. Cole and Bowers, "Research Article Productivity of U.S. Journalism Faculties," p.246.

4. Paula De Simone Watson, "Publication Activity Among Academic Librarians," College \& Research Libraries 38:375-84 (Sept. 1977).

5. John N. Olsgaard and Jane Kinch Olsgaard, "Authorship in Five Library Periodicals," College \& Research Libraries 41:49-53 (Jan. 1980).

6. Ronald Rayman and Frank W. Goudy, "Research and Publication Requirements in University Libraries," College \& Research Libraries 41:43-48 (Jan. 1980).

7. Thomas G. English, "Librarian Status in the Eighty-Nine U.S. Academic Institutions of the Association of Research Libraries," College \& Research Libraries 44:203-4 (May 1983).

8. Olsgaard and Olsgaard, "Authorship in Five Library Periodicals," p.51.

9. English, "Librarian Status in the Eighty-nine U.S. Academic Institutions," p.199-211.

10. Ibid., p.211.

11. Ibid., p. 207.

12. Ibid., p.211.

13. To quote English, "According to the administrator at the University of Oregon, a significant number of librarians were placed in increasing jeopardy because of the difficulty of meeting faculty tenure requirements. Consequently, in $1980, \ldots$ librarians . . . were presented with the choice of remaining officers of instruction, the same personnel category as the teaching faculty, or becoming officers of administration, a second faculty category; according to officials at the University of Oregon, 'The purpose of the shift was to remove from professional librarians some of the burden of research and publication required by those teaching faculty seeking promotion and tenure'. . . . According to the University librarian, roughly 50 percent of the library staff at Oregon elected to 
switch to the officer of administration category. At the same time, it was concluded that all new librarian appointments would be placed in the latter classification. . . . [It] was projected that, by 1990, the conversion to officers of administration would be complete." English, "Librarian Status in the Eighty-Nine U.S. Academic Institutions," p.206.

14. Ibid., p.201, 204.

15. For a more complete discussion of the development of faculty status at the University of Illinois, see Robert G. Sewell, "Faculty Status and Librarians: The Rationale and the Case of Illinois," College \& Research Libraries 44:212-22 (May 1983).

16. English gives no attention to the weighting of the various factors in evaluation (e.g., job performance, professional service, research and publication). In an as yet unpublished survey of ARL reference departments, this author queried respondents as to the weighting of the various factors in both promotion/tenure decisions and annual salary determinations. Twenty-eight institutions with faculty status replied to these questions. Only four reported that publications were weighted from 30 to 50 percent in promotion/tenure decisions; only two (Illinois and Michigan State) reported significant weighting (at least 33 percent) in decisions concerning annual salaries. (This study was primarily concerned with the organization and functions of reference departments in the academic members of the RASD Discussion Groups on Reference Services in Large and Medium-Sized Research Libraries and was pursued under the auspices of both discussion groups.)

17. J. Periam Danton, "Notes on the Evaluation of Library Schools," Journal of Education for Librarianship 24:106-16 (Fall 1983).

18. R. M. Hayes, "Citation Statistics as a Measure of Faculty Research Productivity," Journal of Education for Librarianship 23:151-72 (Winter 1983).

19. Russell E. Bidlack, "A Statistical Survey of 67 Library Schools, 1978-79," Journal of Education for Librarianship 19:321 (Spring 1979). 